\title{
Novel Proinflammatory Function of Renal Intercalated Cells
}

\author{
Sylvie Breton Dennis Brown \\ Center for Systems Biology, Program in Membrane Biology/Nephrology Division, Massachusetts General Hospital, \\ Harvard Medical School, Boston, MA, USA
}

\section{Keywords}

Kidney inflammation - UDP-glucose · Purinergic receptors .

Kidney collecting duct · Neutrophil infiltration

\section{Abstract}

Background: Serious and often fatal acute kidney injury (AKI) is frequently seen after major surgery, local and remote organ damage, and sepsis. It is associated with uncontrolled inflammation, and is usually diagnosed only after the kidneys have gone through significant and often irreversible damage. Summary: During our work involving another type of kidney disease that leads to acid-base disorders of the blood, we unexpectedly found high levels of a protein called the $\mathrm{P}_{2} \mathrm{Y}_{14}$ "purinergic" receptor, in specialized kidney epithelial cells called intercalated cells (ICs). These cells are responsible for maintaining whole body acid-base balance by regulating the secretion of excess protons into the urine, which normalizes blood $\mathrm{pH}$. However, it turns out that the $\mathrm{P}_{2} \mathrm{Y}_{14}$ receptor in these cells responds to a molecule called uridine diphosphate (UDP)-glucose, which is a danger signal released by damaged cells anywhere in the body. When UDP-glucose reaches the kidney, it stimulates ICs to produce chemoattractant cytokines; this results in renal inflam- mation and contributes to the onset of AKI. Key Message: Thus, our work now points to ICs as key mediators of renal inflammation and $\mathrm{AKI}$, following surgery and/or damage to remote organs, sepsis, and also local insults to the kidney itself. The link between the proton secreting ICs of the kidney and AKI is an example of how a fundamental research project with a defined aim, in this case understanding acidbase homeostasis, can lead to a novel observation that has unexpected but major implications in another area of human health.

(c) 2018 The Author(s)

Published by S. Karger AG, Basel

\section{Introduction}

Renal intercalated cells (ICs) are best known for their central role in the regulation and maintenance of acidbase balance via the proton-pumping activity of the vacuolar $\mathrm{H}^{+}$-ATPase (V-ATPase), and other membrane associated ion transporters. However, we recently made the unexpected discovery that in addition to this important physiological role, type A proton secreting ICs (AICs) are also sensors that mediate sterile inflammation

\begin{tabular}{|c|c|}
\hline KARGER & $\begin{array}{l}\text { (c) } 2018 \text { The Author(s) } \\
\text { Published by S. Karger AG, Basel }\end{array}$ \\
\hline $\begin{array}{l}\text { E-Mail karger@karger.com } \\
\text { www.karger.com/anm }\end{array}$ & $\begin{array}{l}\text { This article is licensed under the Creative Commons Attribution- } \\
\text { NonCommercial-NoDerivatives } 4.0 \text { International License (CC BY- } \\
\text { NC-ND) (http://www.karger.com/Services/OpenAccessLicense). } \\
\text { Usage and distribution for commercial purposes as well as any dis- } \\
\text { tribution of modified material requires written permission. }\end{array}$ \\
\hline
\end{tabular}

Dennis Brown, $\mathrm{PhD}$

Program in Membrane Biology and Division of Nephrology Massachusetts General Hospital, Simches Research Center 1854 Cambridge Street, Boston, MA 02114 (USA)

E-Mail brown.dennis@mgh.harvard.edu 
in the kidney medulla [1]. This resulted from our identification of high expression of the proinflammatory uridine diphosphate (UDP)-glucose receptor $\mathrm{P}_{2} \mathrm{Y}_{14}$ in A-ICs.

Renal failure (i.e., in acute kidney injury [AKI] brought on by surgery, local and remote organ damage, and sepsis) is often associated with uncontrolled inflammation [2]. Prolonged episodes of dehydration also can result in AKI and chronic kidney disease (CKD) [3]. In addition, acidosis is a comorbidity and co-mortality factor in AKI [4]. In this context, we discuss here the wellestablished role of A-ICs in acid-base homeostasis, and the newly discovered proinflammatory role of these cells.

\section{AKI - The Silent Killer}

Regardless of the cause of hospitalization, all patients admitted to the intensive care unit (ICU) are at a high risk of developing AKI [5]. On a yearly basis, up to two thirds of the 5.7 million ICU patients in the United States develop AKI [6, 7]. Overall, AKI affects 1 in 5 hospitalized adults, and 1 in 3 hospitalized children [8]. In addition, patients who survive AKI have an increased chance of developing CKD and end-stage renal disease [9]. However, AKI often remains undetected due to the lack of adequate biomarkers of early renal injury, and very few therapeutic options are currently available to alleviate AKI $[10,11]$. This leads to AKI sometimes being referred to as "the silent killer." A recent review article stated, "Given the high mortality and morbidity associated with AKI, there is an important unmet medical need to develop effective therapies for these patients" [11]. In this context, the field is in dire need of a biomarker that can detect early signs of renal injury, and new treatments that could be administered while injury can be prevented. This would enable the physician to make vital clinical decisions before the damage progresses to potentially fatal renal failure.

Multiple primary clinical conditions are associated with AKI, especially cardiac surgery, myocardial infarction (MI) and sepsis. AKI occurs in 30\% of patients after cardiac surgery and in $22 \%$ of patients after MI [12]. These patients are then at high risk of multiple organ failure and death. In addition, sepsis is responsible for over $50 \%$ of cases of AKI in the ICU $[4,11]$. Thus, the means by which diverse organ systems communicate damage to the kidney, which leads to AKI, is of great current interest in the nephrology field.

\section{Purinergic Signaling in the Kidney}

Uncontrolled inflammation is a major cause of AKI [2]. Following immune cell chemotaxis and infiltration, production of reactive oxygen species, eicosanoids, and leukocyte- and endothelial cell-derived mediators create an intense inflammation reaction that potentiates renal injury $[13,14]$. Purinergic signaling has been shown to participate in the onset of renal inflammation, but the underlying mechanisms involved, and how to prevent and alleviate the severe damage caused by inflammation, still remain to be fully characterized. Purinergic receptors respond to extracellular purines and pyrimidines, and they modulate a variety of cellular functions [15]. $\mathrm{P} 2 \mathrm{X}$ receptors are ligand-gated ion channels and their principal selective agonist is adenosine triphosphate (ATP), while $\mathrm{P} 2 \mathrm{Y}$ receptors are $\mathrm{G}$ protein-coupled receptors that respond to a variety of adenine and uracil nucleotides, including ATP, adenosine diphosphate (ADP), uridine triphosphate (UTP), UDP, and UDP-sugars. Several purinergic receptors are present along the renal tubule, and numerous pathologies are associated with dysregulation of purinergic signaling, including hypertension, CKD, AKI, diabetic nephropathy, and glomerulonephritis $[16,17]$. Purinergic receptors present in the renal collecting duct principal cells regulate water, electrolyte, and volume homeostasis $[18,19]$. We recently showed that the adenosine receptors ADORA2A and ADORA2B, located in the apical membrane of the collecting duct ICs, stimulate proton secretion via activation of the cAMP/PKA pathway [20]. In this review article, we describe how another member of the purinergic family, the proinflammatory receptor $\mathrm{P}_{2} \mathrm{Y}_{14}$, mediates renal inflammation via ICs [1], and suggest how this might be applicable to the diagnosis and treatment of AKI.

\section{Identification of the $\mathrm{P}_{2} \mathrm{Y}_{14}$ Receptor in Collecting Duct ICs}

The $\mathrm{P}_{2} \mathrm{Y}_{14}$ receptor (also known as GPR105) is specifically activated by nucleotide sugars [21]. In contrast to other P2Y receptors, it is insensitive to ADP, ATP, and UTP, but its specific ligand has been identified as UDP-glucose. Extracellular ATP, adenosine, and UDP-glucose are immune-regulatory factors known as DAMPs (damage associated molecular pattern) molecules [22]. DAMPs initiate sterile inflammatory reactions, while PAMPs (pathogen associated molecular patterns) trigger infectious proinflammatory responses $[22,23]$. UDP-glucose is released by
Breton/Brown 

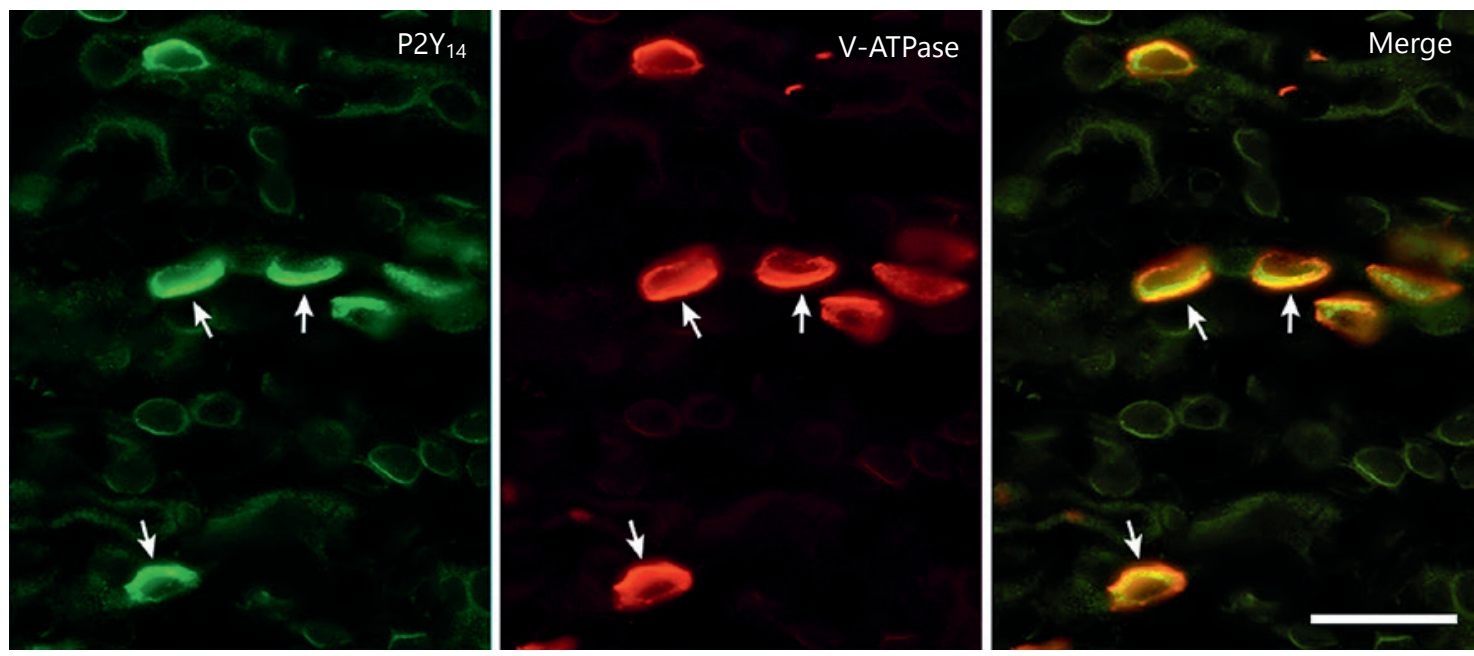

Fig. 1. Immunofluorescence localization of $\mathrm{P}_{2} \mathrm{Y}_{14}$ in the apical membrane of type A intercalated cells (ICs). Double-labeling for the IC marker V-ATPase (red), and $\mathrm{P}_{2} \mathrm{Y}_{14}$ (green) on a section of fixed kidney medulla using specific antibodies against these

injured cells and acts as an autocrine activator of the $\mathrm{P} 2 \mathrm{Y}_{14}$ receptor [24]. In contrast to most nucleotides, which are rapidly degraded by ectonucleotidases after their release, UDP-glucose resists hydrolysis by these enzymes [25].

$\mathrm{P}_{2} \mathrm{Y}_{14}$ is an inflammatory mediator that is expressed in immune cells [26-28], the brain, gastrointestinal tract, kidney, and lungs $[1,21,29]$. Patients with cystic fibrosis and asthma have elevated concentrations of UDP-glucose in their lungs [30, 31], and $\mathrm{P}_{2} \mathrm{Y}_{14}$ activation by UDP-glucose in airway epithelial cells leads to interleukin 8 secretion and an inflammatory response [32]. Furthermore, mouse uterus injection of UDP-glucose induces the recruitment of neutrophils into the endometrium [33]. In addition, $\mathrm{P}_{2} \mathrm{Y}_{14}$ mRNA expression is upregulated by lipopolysaccharides, further indicating its role in mediating inflammation $[33,34]$.

Our recent screening of the proteome and transcriptome of ICs unexpectedly revealed very high expression levels of the purinergic receptor $\mathrm{P}_{2} \mathrm{Y}_{14}$ [1]. ICs were isolated by fluorescence activated cell sorting from previously characterized transgenic mice that express enhanced green fluorescent protein (EGFP) specifically in these cells (B1-EGFP mice) [35]; no expression was detected in all other renal cell types [1]. In addition, RNA sequencing of isolated EGFP ICs identified $\mathrm{P}_{2} \mathrm{Y}_{14}$ as one of the most expressed genes in these cells, whilesingle cell RNA sequencing showed specific expression of $\mathrm{P}_{2} \mathrm{Y}_{14}$ in type A ICs [36]. Subsequent examination showed that $\mathrm{P}_{2} \mathrm{Y}_{14}$ is located on the apical surface of ICs in contact with the tubular fluid (pre-urine; Fig. 1).

Novel Proinflammatory Function of Renal ICs proteins. $\mathrm{P}_{2} \mathrm{Y}_{14}$ is expressed on the apical membrane (urinary side) of A-ICs, where it co-localizes with the V-ATPase (arrows and yellow in merge panel). Scale bar $=20 \mu \mathrm{m}$.

\section{The Novel Role of ICs in Renal Inflammation: Implications for the Onset of AKI}

Treatment of mice with a single i.v. injection of UDP$\mathrm{G}$ increased proinflammatory chemokine expression in ICs isolated $4 \mathrm{~h}$ later by fluorescence activated cell sorting from transgenic mice [1]. In cultured MDCK-C11 cells, which also express P2Y14, UDP-G treatment increased ERK1/2 phosphorylation and upregulated chemokine mRNAs through the activation of P2Y14 [1]. Flow cytometry analysis showed a robust renal neutrophil infiltration 2 days after UDP-G administration in mice, and neutrophils were often seen in dose proximity to ICs. We did not detect $\mathrm{P}_{2} \mathrm{Y}_{14}$ in murine neutrophils, so it is unlikely that UDP-G acted directly on these cells to induce chemotaxis in an autocrine manner [1]. These results indicated a novel role for ICs as sensors, mediators, and effectors of sterile inflammation in the kidney via $\mathrm{P} 2 \mathrm{Y}_{14}$. We suggest that, by their ability to produce chemokines, ICs act as immune defense cells by creating a chemotaxic gradient favorable to immune cell recruitment (Fig. 2).

This study enhanced our understanding of how a local insult to the kidney and also a distant injury to another organ are able to communicate damage to the kidney through the activation of the proinflammatory receptor $\mathrm{P}_{2} \mathrm{Y}_{14}$ located in renal ICs. Our working hypothesis is that UDP-G (i.e., released from injured renal proximal tubules during ischemia reperfusion injury, cardiomyocytes during $\mathrm{MI}$, or cells damaged in sepsis) is a circulating biological mediator 
Fig. 2. Proposed mode of action of UDP-G in mediating inter-and intra-organ crosstalk resulting in renal inflammation. UDP-G is released from cells injured during myocardial infarction (MI), sepsis, or proximal tubule ischemic injury. UDP-G released from these injured cells either in remote organs such as the heart, or more locally in the kidney itself, is delivered to the lumen of the kidney collecting duct, where it binds to the $\mathrm{P}_{2} \mathrm{Y}_{14}$ receptor located on the apical surface of A-ICs. This receptor-ligand interaction stimulates the production of proinflammatory chemokine (PICS) by ICs, which attract neutrophils from the circulation into the kidney.

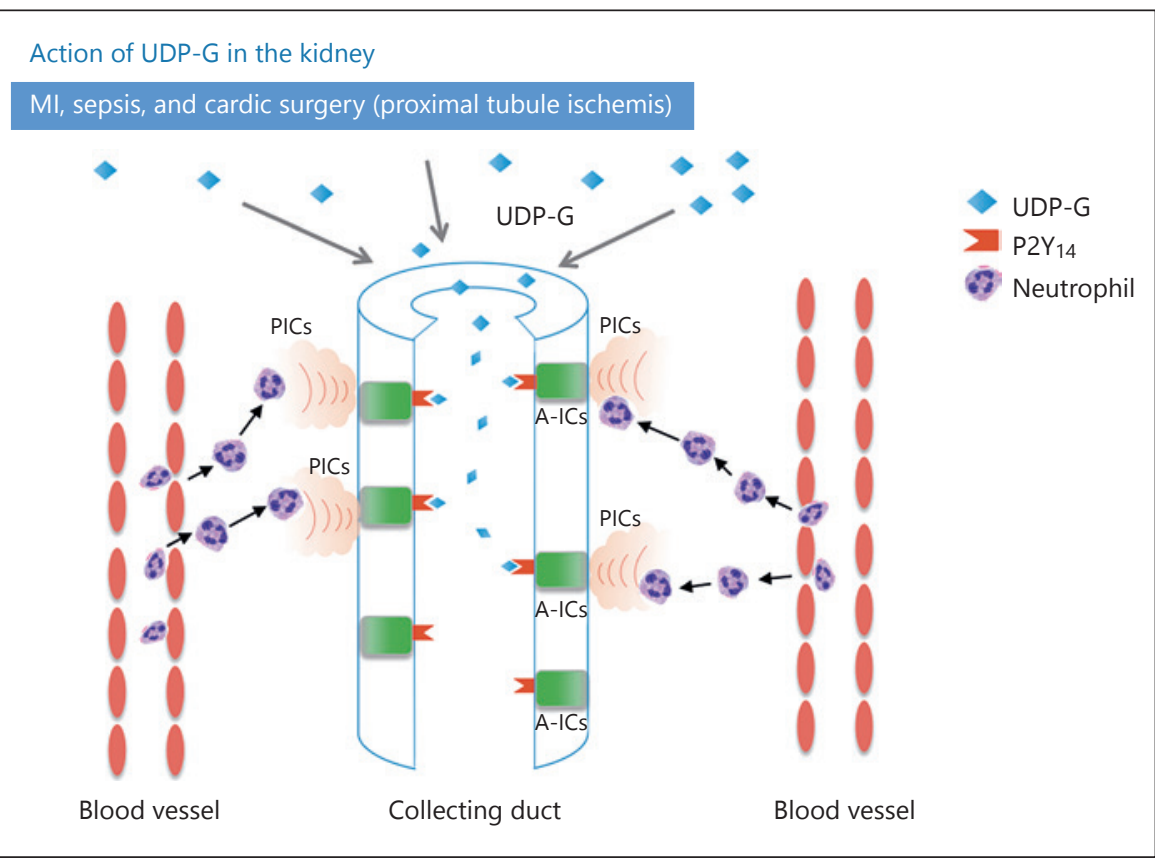

that initiates intra- and inter-organ crosstalk and causes renal inflammation and AKI (Fig. 2). Why would UDP-G affect the kidneys more than any other organ in the body? One of the main roles of the kidneys is to remove metabolites such as UDP-G from the blood, while maintaining a constant blood volume. During this process, serum UDP$\mathrm{G}$ is filtered by glomeruli and is delivered to the urinary compartment of the kidney. Upon water extraction from the collecting duct, by the aquaporin-dependent renal concentrating mechanism [37], UDP-G is then concentrated in the lumen of the collecting duct to a critical point where it initiates local inflammation through the activation of P2 $\mathrm{Y}_{14}$ located in the apical membrane of ICs [1].

\section{Role of ICs in Acid-Base Regulation}

ICs secrete protons and are located along the collecting duct of the kidney, where they are interspersed among the water-reabsorbing principal cells (Fig. 3). Up until the recent discovery of their immune function described above, they were best known as regulators of systemic acid-base balance. They survey the local environment and rapidly adjust the amount of a critical enzyme, the proton pump or V-ATPase, at the cell surface to control blood $\mathrm{pH}$ by expelling protons into the urine (Fig. 3) [38-41]. Interestingly, a subset of ICs can work in the reverse direction, by pumping protons into the blood and secreting bicarbonate into the tubule lumen. This process is activated when blood

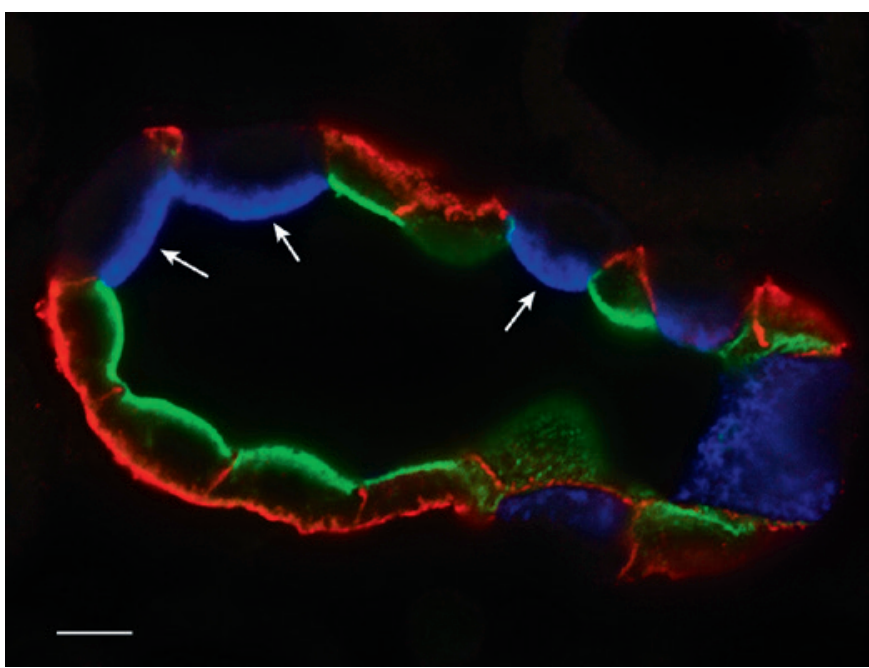

Fig. 3. Immunofluorescence identification of different cell types in the collecting duct. Triple-labeling for V-ATPase (blue), aquaporin 2 (green) and aquaporin 4 (red) of fixed kidney medulla. A-ICs express the V-ATPase in their apical membrane (arrows), consistent with their function of secreting protons into the tubule lumen. The adjacent principal cells express apical aquaporin 2 (green) and basolateral aquaporin 4 (red), consistent with their role in water reabsorption from the tubule. Scale bar $=5 \mu \mathrm{m}$.

$\mathrm{pH}$ becomes too alkaline [38]. One of the major pathways positively or negatively regulating the amount of active $\mathrm{V}$ ATPase at the cell surface is the vesicular shuttling of VATPase molecules to and from the cell surface by exo- and 
endocytosis of very unique V-ATPase-rich vesicles. Readers interested in this cell biological process are directed toward review articles on this topic [38, 41, 42].

While acid-base disturbances have multiple origins, deficient V-ATPase function results in acid buildup in the body, leading to acidemia and childhood-onset distal renal tubule acidosis. If undiagnosed and untreated, distal renal tubule acidosis may lead to failure to thrive, growth retardation, osteomalacia or rickets, nephrocalcinosis or nephrolithiasis, kidney failure, and even death in infancy [43]. The V-ATPase is a very complex enzyme formed of at least 13 different protein subunits [38]. Loss of function mutations in some of these subunits in mice and humans results in persistently high urine $\mathrm{pH}$, hypobicarbonatemia, hypercalciuria, hypocitraturia, and hypokalemia, often with progressive sensorineural hearing loss [44] and olfactory defects in mice [45].

Thus, the majority of research directed toward these cells in the past has understandably focused on their central role in acid-base regulation. However, 2 previous reports also have implicated ICs in defending the urinary tract against bacterial infection through the Toll-like receptor-4-mediated innate immunity pathway, which recognizes urinary pathogens, in particular uropathogenic Escherichia coli $[46,47]$. Together with our more recent data, a new function for ICs in defending against bacterial infection and mediating sterile inflammation is emerging.

\section{Conclusion}

The link between proton-secreting ICs of the kidney and AKI is an excellent example of how a fundamental research project with a defined aim, in this case under- standing acid-base homeostasis, can lead to an unexpected finding that has major implications for human health. While examining proteins expressed by ICs in the context of their proton secretory activity, we were struck by the high expression levels of the $\mathrm{P}_{2} \mathrm{Y}_{14}$ protein and set out to examine its role in IC biology. This led us to the discovery that its ligand, UDP-glucose, is a danger-signaling molecule, released by damaged cells, that moves into the kidney and stimulates ICs to produce chemoattractant cytokines, which provoke renal inflammation that is implicated in the onset of AKI. Many known conditions lead to AKI, and individuals who have experienced an episode of AKI in many cases are more prone to develop CKD in the future. We anticipate, therefore, that by understanding the basic cellular mechanisms that are involved in AKI pathogenesis, we can develop new strategies to prevent the development of AKI, which will in turn reduce the incidence of CKD in the population.

\section{Acknowledgments and Disclosure Statement}

The studies from the authors' laboratories that are summarized in this review were supported by grants from the National Institutes of Health HD040793 and DK097124 (to S.B.), DK042956 (to D.B). S.B. is a recipient of the Charles and Ann Sanders Research Scholar Award at Massachusetts General Hospital.

S.B. has a financial interest in Kantum Diagnostic, Inc., (doing business as Kantum Bio) a company developing a diagnostic and therapeutic combination to prevent and treat AKI. The interests of S.B. were reviewed and are managed by Massachusetts General Hospital and Partners HealthCare, in accordance with their conflict of interest policies. D.B. and S.B. received from Danone Nutricia Research the reimbursement of travel expenses and registration fee to attend the 2017 Hydration for Health scientific conference.

\section{References}

1 Azroyan A, Cortez-Retamozo V, Bouley R, Liberman R, Ruan YC, Kiselev E, Jacobson KA, Pittet MJ, Brown D, Breton S: Renal intercalated cells sense and mediate inflammation via the P2Y14 receptor. PLoS One 2015; 10:e0121419.

2 Rabb H, Griffin MD, McKay DB, Swaminathan S, Pickkers P, Rosner MH, Kellum JA, Ronco C; Acute Dialysis Quality Initiative Consensus XIII Work Group: Inflammation in AKI: current understanding, key questions, and knowledge gaps. J Am Soc Nephrol 2016; 27:371-379.

3 Roncal-Jimenez C, Lanaspa MA, Jensen T, Sanchez-Lozada LG, Johnson RJ: Mechanisms by which dehydration may lead to chronic kidney disease. Ann Nutr Metab 2015; 66(suppl 3):10-13.

4 Swaminathan S, Rosner MH, Okusa MD: Emerging therapeutic targets of sepsis-associated acute kidney injury. Semin Nephrol 2015;35:38-54.

5 Chertow GM, Burdick E, Honour M, Bonventre JV, Bates DW: Acute kidney injury, mortality, length of stay, and costs in hospitalized patients. J Am Soc Nephrol 2005; 16:3365-3370.

6 Honore PM, Jacobs R, Joannes-Boyau O, Verfaillie L, De Regt J, Van Gorp V, De Waele E, Boer W, Collin V, Spapen HD: Biomarkers for early diagnosis of AKI in the ICU: ready for prime time use at the bedside? Ann Intensive Care 2012;2:24.
7 Roste EA, Schurgers M: Epidemiology of acute kidney injury: how big is the problem? Crit Care Med 2008;36:S146-S151.

8 Susantitaphong P, Cruz DN, Cerda J, Abulfaraj M, Alqahtani F, Koulouridis I, Jaber BL; Acute Kidney Injury Advisory Group of the American Society of Nephrology: World incidence of AKI: a meta-analysis. Clin J Am Soc Nephrol 2013;8:14821493.

9 Bonventre JV, Basile D, Liu KD, McKay D, Molitoris BA, Nath KA, Nickolas TL, Okusa MD, Palevsky PM, Schnellmann R, RysSikora K, Kimmel PL, et al: AKI: a path forward. Clin J Am Soc Nephrol 2013;8:16061608. 
10 Kaushal GP, Shah SV: Challenges and advances in the treatment of AKI. J Am Soc Nephrol 2014;25:877-883.

11 Skrypnyk NI, Siskind LJ, Faubel S, de Caestecker MP: Bridging translation for acute kidney injury with better preclinical modeling of human disease. Am J Physiol Renal Physiol 2016;310:F972-F984.

12 Vives M, Wijeysundera D, Marczin N, Monedero P, Rao V: Cardiac surgery-associated acute kidney injury. Interact Cardiovasc Thorac Surg 2014;18:637-645.

13 Awad AS, Rouse M, Huang L, Vergis AL, Reutershan J, Cathro HP, Linden J, Okusa MD: Compartmentalization of neutrophils in the kidney and lung following acute ischemic kidney injury. Kidney Int 2009;75:689-698.

14 Bonventre JV, Zuk A: Ischemic acute renal failure: an inflammatory disease? Kidney Int 2004;66:480-485.

15 Jacobson KA, Muller CE: Medicinal chemistry of adenosine, $\mathrm{P} 2 \mathrm{Y}$ and $\mathrm{P} 2 \mathrm{X}$ receptors. Neuropharmacology 2016;104:31-49.

16 Arulkumaran N, Turner CM, Sixma ML, Singer M, Unwin R, Tam FW: Purinergic signaling in inflammatory renal disease. Front Physiol 2013;4:194.

17 Burnstock G, Evans LC, Bailey MA: Purinergic signalling in the kidney in health and disease. Purinergic Signal 2014;10:71-101.

18 Praetorius HA, Leipziger J: Intrarenal purinergic signaling in the control of renal tubular transport. Annu Rev Physiol 2010;72:377-393.

19 Rieg T, Vallon V: ATP and adenosine in the local regulation of water transport and homeostasis by the kidney. Am J Physiol Regul Integr Comp Physiol 2009;296:R419-R427.

20 Battistone MA, Barton CR, Liberman RN, Nair A, Peralta MA, Capen DE, Brown D, Breton S: Extracellular adenosine stimulates V-ATPasedependent proton secretion in renal intercalated cells. JASN 2017, under review.

21 Chambers JK, Macdonald LE, Sarau HM, Ames RS, Freeman K, Foley JJ, Zhu Y, McLaughlin MM, Murdock P, McMillan L, Trill J, Swift A, et al: A G protein-coupled receptor for UDP-glucose. J Biol Chem 2000; 275:10767-10771.

22 Chen GY, Nunez G: Sterile inflammation: sensing and reacting to damage. Nat Rev Immunol 2010;10:826-837.

23 Kono H, Rock KL: How dying cells alert the immune system to danger. Nat Rev Immunol 2008;8:279-289.

24 Lazarowski ER, Shea DA, Boucher RC, Harden TK: Release of cellular UDP-glucose as a potential extracellular signaling molecule. Mol Pharmacol 2003;63:1190-1197.

25 Zimmermann H: Extracellular metabolism of ATP and other nucleotides. Naunyn Schmiedebergs Arch Pharmacol 2000;362:299-309.
26 Gao ZG, Ding Y, Jacobson KA: UDP-glucose acting at $\mathrm{P} 2 \mathrm{Y} 14$ receptors is a mediator of mast cell degranulation. Biochem Pharmacol 2010;79:873-879.

27 Scrivens M, Dickenson JM: Functional expression of the $\mathrm{P} 2 \mathrm{Y} 14$ receptor in murine $\mathrm{T}$ lymphocytes. Br J Pharmacol 2005; 146:435444.

28 Scrivens M, Dickenson JM: Functional expression of the $\mathrm{P} 2 \mathrm{Y} 14$ receptor in human neutrophils. Eur J Pharmacol 2006;543:166-173.

29 Freeman K, Tsui P, Moore D, Emson PC, Vawter L, Naheed S, Lane P, Bawagan H, Herrity N, Murphy K, Sarau HM, Ames RS, et al: Cloning, pharmacology, and tissue distribution of G-protein-coupled receptor GPR105 (KIAA0001) rodent orthologs. Genomics 2001;78:124-128.

30 Okada SF, Zhang L, Kreda SM, Abdullah LH, Davis CW, Pickles RJ, Lazarowski ER, Boucher RC: Coupled nucleotide and mucin hypersecretion from goblet-cell metaplastic human airway epithelium. Am J Respir Cell Mol Biol 2011;45:253-260

31 Sesma JI, Esther CR Jr, Kreda SM, Jones L, O'Neal W, Nishihara S, Nicholas RA, Lazarowski ER: Endoplasmic reticulum/golgi nucleotide sugar transporters contribute to the cellular release of UDP-sugar signaling molecules. J Biol Chem 2009;284:1257212583.

32 Muller T, Bayer H, Myrtek D, Ferrari D, Sorichter S, Ziegenhagen MW, Zissel G, Virchow JC Jr, Luttmann W, Norgauer J, Di Virgilio F, Idzko M: The P2Y14 receptor of airway epithelial cells: coupling to intracellular $\mathrm{Ca} 2+$ and IL-8 secretion. Am J Respir Cell Mol Biol 2005;33:601-609.

33 Arase T, Uchida H, Kajitani T, Ono M, Tamaki K, Oda H, Nishikawa S, Kagami M, Nagashima T, Masuda $\mathrm{H}$, Asada $\mathrm{H}$, Yoshimura $\mathrm{Y}$, et al: The UDP-glucose receptor P2RY14 triggers innate mucosal immunity in the female reproductive tract by inducing IL- 8 . J Immunol 2009;182:7074-7084.

34 Moore DJ, Murdock PR, Watson JM, Faull RL, Waldvogel HJ, Szekeres PG, Wilson S, Freeman KB, Emson PC: GPR105, a novel Gi/o-coupled UDP-glucose receptor expressed on brain glia and peripheral immune cells, is regulated by immunologic challenge: possible role in neuroimmune function. Brain Res Mol Brain Res 2003;118:10-23.

35 Miller RL, Lucero OM, Riemondy KA, Baumgartner BK, Brown D, Breton S, Nelson $\mathrm{RD}$ : The V-ATPase B1-subunit promoter drives expression of Cre recombinase in intercalated cells of the kidney. Kidney Int 2009; 75:435-439.

36 Chen L, Lee JW, Chou CL, Nair AV, Battistone MA, Paunescu TG, Merkulova M, Bret- on S, Verlander JW, Wall SM, Brown D, Burg $\mathrm{MB}$, et al: Transcriptomes of major renal collecting duct cell types in mouse identified by single-cell RNA-Seq. Proc Natl Acad Sci U S A 2017;114:E9989-E9998.

37 Brown D: The discovery of water channels (Aquaporins). Ann Nutr Metab 2017; 70(suppl 1):37-42.

38 Wagner CA, Finberg KE, Breton S, Marshansky V, Brown D, Geibel JP: Renal vacuolar H+-ATPase. Physiol Rev 2004;84:12631314.

39 Wagner CA, Kovacikova J, Stehberger PA, Winter C, Benabbas C, Mohebbi N: Renal acid-base transport: old and new players. Nephron Physiol 2006;103:p1-p6.

40 Brown D, Wagner CA: Molecular mechanisms of acid-base sensing by the kidney. J Am Soc Nephrol 2012;23:774-780.

41 Roy A, Al-bataineh MM, Pastor-Soler NM: Collecting duct intercalated cell function and regulation. Clin J Am Soc Nephrol 2015;10: 305-324.

42 Breton S, Brown D: Regulation of luminal acidification by the V-ATPase. Physiology (Bethesda) 2013;28:318-329.

43 Feldman M, Prikis M, Athanasiou Y, Elia A, Pierides A, Deltas CC: Molecular investigation and long-term clinical progress in Greek Cypriot families with recessive distal renal tubular acidosis and sensorineural deafness due to mutations in the ATP6V1B1 gene. Clin Genet 2006;69:135-144.

44 Stover EH, Borthwick KJ, Bavalia C, Eady N, Fritz DM, Rungroj N, Giersch AB, Morton CC, Axon PR, Akil I, Al-Sabban EA, Baguley DM, et al: Novel ATP6V1B1 and ATP6V0A4 mutations in autosomal recessive distal renal tubular acidosis with new evidence for hearing loss. J Med Genet 2002;39: 796-803.

45 Paunescu TG, Rodriguez S, Benz E, McKee M, Tyszkowski R, Albers MW, Brown D: Loss of the V-ATPase B1 subunit isoform expressed in non-neuronal cells of the mouse olfactory epithelium impairs olfactory function. PLoS One 2012;7:e45395.

46 Chassin C, Goujon JM, Darche S, du Merle L, Bens M, Cluzeaud F, Werts C, Ogier-Denis E, Le Bouguenec C, Buzoni-Gatel D, Vandewalle A: Renal collecting duct epithelial cells react to pyelonephritis-associated Escherichia coli by activating distinct TLR4-dependent and -independent inflammatory pathways. J Immunol 2006;177:4773-4784.

47 Paragas N, Kulkarni R, Werth M, SchmidtOtt KM, Forster C, Deng R, Zhang Q, Singer E, Klose AD, Shen TH, Francis KP, Ray S, et al: $\alpha$-Intercalated cells defend the urinary system from bacterial infection. J Clin Invest 2014;124:2963-2976. 